Category III (corresponding to atrophic gastritis or mucosal atrophy on histological examination).- There are irregular, broad, leaf-shaped mucosal folds and convolutions which are sometimes arranged in the form of rosettes (Special Plate, Fig. 3). The openings of gastric glands are usually invisible. (Note that particular attention should be given to the periphery of the specimen when studying these appearances.)

\section{Appearances of Normal Pyloric and Cardiac Mucosa}

These are different from those of normal fundic mucosa. In pyloric mucosa, the mucosa is arranged in a uniform mosaic or fish-scale pattern, with several normal papillae in each part of the pattern (Special Plate, Fig. 4). The cardiac mucosa is similar but the pattern is less coarse, with fewer papillae in each subdivision.

In gastritis the pattern is commonly similar to that of category III of the fundic mucosa.

\section{Discussion}

Holmes et al. (1961) were the first to point out that examination of a small-intestinal biopsy specimen permitted immediate recognition of normal villi, abnormal villi, or the flattened mucosa of subtotal villous atrophy. Subsequent work has confirmed the validity of this observation, and we have found the method useful in our own studies (Salem et al., 1964a).

In a similar fashion, it appears that inspection of a gastric biopsy specimen under the dissecting microscope enables the diagnosis of gastritis to be made immediately. If the gastritis is patchy, as in some examples of chronic superficial gastritis, this fact is immediately evident and may be a guide to subsequent choice of area for histological examination.

\section{Summary}

Gastric biopsy specimens from 48 patients have been examined under the dissecting microscope and the appearances correlated with subsequent histological findings.

The fundic mucosal appearances can be divided into three categories which correspond to normal histology, chronic superficial gastritis, and atrophic gastritis or gastric mucosal atrophy. The agreement between the dissecting-microscope appearances and the histological examination is almost perfect.

Normal pyloric mucosa and cardiac mucosa each differ from normal fundic mucosa under the dissecting microscope but show analogous changes when there is gastritis.

Examination of a gastric biopsy specimen under the dissecting microscope therefore permits of the immediate diagnosis of gastritis with a high measure of confidence.

\section{REFERENCES} Crosby, W. H., and Kugler, H. W. (1957). Amer. F. dig. Dis., 2, 236.
Floch, M. H., and Sheehy, T. W. (1962). Gastroenterology, 43, 32. Holmes, R., Hourihane, D. O'B., and Booth, C. C. (1961). Lancet, 1, 81. Salem, S. N., Truelove, S. C., and Richards, W. C. D. (1964a). Brit. med. F., 1, 394.

Wo

Wood, I. J., Doig, R. K., Motteram, R., and Hughes, A. (1949). Lancet, 1,18 .

\title{
Red-cell Aplasia with Carcinoma of the Bronchus
}

\author{
C. C. ENTWISTLE* M.B., CH.B. ; P. H. FENTEM,* M.SC., M.B., CH.B. ; A. JACOBS,* M.D., M.C.PATH.
}

The literature contains 83 reports of pure red-cell aplasia (Andersen and Ladefoged, 1963 ; Schmid, Kiely, Pease, and Hargraves, 1963). An association with a thymic tumour has been demonstrated in 44 cases, but the condition has not been described with other tumours. The present report describes a patient in whom red-cell aplasia occurred together with a bronchial carcinoma. The serum of this patient contained a factor which inhibited erythropoiesis in rabbits but which was absent after irradiation of the tumour.

\section{Case Report}

A man aged 68 attended his doctor for a routine medical examination prior to his retirement from a job as a labourer in the engineering industry. He was found to be pale and was referred to Cardiff Royal Infirmary in February 1961 for investigation. His only complaint was that of tiredness. He had smoked at least 20 cigarettes each day for many years and had experienced a productive cough for three years.

Physical examination confirmed the mucosal pallor. His spleen was palpable on deep inspiration but there were no other abnormal physical signs.

Investigations.-Haemoglobin 6.7 g. $/ 100 \mathrm{ml}$. M.C.H.C. $32 \%$. M.C.V. 140 cubic microns. Reticulocyte count $1 \%$. W.B.C. 3,900 /

* From the Medical Unit and Department of Pathology, Welsh National School of Medicine, Cardiff Royal Infirmary. c.mm., normal differential count. Platelets $265,000 /$ c.mm. Blood film: normochromic macrocytic red cells, with anisocytosis and poikilocytosis. E.S.R. $50 \mathrm{~mm}$. in 1 hour (Westergren). Direct Coombs test negative. Serum vitamin $B_{12} 141 \mu \mu \mathrm{g} . / \mathrm{ml}$. Serum proteins: total $6.7 \mathrm{~g} . / 100 \mathrm{ml}$. (albumin $4.0 \mathrm{~g}$.). Blood urea $33 \mathrm{mg} . /$ $100 \mathrm{ml}$. Sternal marrow aspirate showed only scanty red-cell precursors, which were normoblastic in type. They comprised $4 \%$ of the total cells. The myeloid series and megakaryocytes were normal. Trephine marrow biopsy from the iliac crest showed slight hypocellularity. Gastric analysis revealed a histamine-fast achlorhydria. Barium-enema examination showed diverticulosis of the colon. Chest radiograph was normal. Faecal occult blood was negative.

The patient made no response to injections of vitamin $B_{12}$ and was believed to have a hypoplastic anaemia. He required blood transfusions to prevent a serious fall in haemoglobin, and during the next 21 months he received 60 pints ( 34 litres) of blood.

Three months after his first admission to hospital he developed a transient pyrexial illness with a polyarthritis involving the lumbar spine, ankles, knees, and hands. The pyrexia responded to penicillin. The cause of the illness was uncertain. His E.S.R. reached $150 \mathrm{~mm}$. in 1 hour (Westergren) but his peripheral white-cell count remained within normal limits. Serum electrophoresis at this time showed a raised gamma-globulin. Shortly after this illness clubbing of the finger-nails was noted for the first time.

In August 1962 the patient's haemoglobin was $11.5 \mathrm{~g} . / 100 \mathrm{ml}$., M.C.H.C. $33 \%$, with the aid of transfused blood. The reticulocyte count was $20,400 / \mathrm{c} . \mathrm{mm}$. and had been at about this level for the previous year. Serum iron was $203 \mu \mathrm{g} . / 100 \mathrm{ml}$. and total iron- 
hinding capacity $232 \mu \mathrm{g} . / 100 \mathrm{ml}$. Studies following an intravenous dose of $5 \mu \mathrm{c}$ of ${ }^{s y} \mathrm{Fe}$-labelled ferric citrate showed the plasma halfclearance time to be 320 minutes (normal 70-140 minutes) and the red-cell utilization at 10 days to be $23 \%$ (normal $75-85 \%$ ). In vivo surface counting showed an unusually large accumulation of radioactivity in the liver after 20 hours and a lesser accumulation in the spleen. No excess counts were detected over the sacral bonemarrow.

In September, when he attended for a further blood transfusion, his voice was hoarse. Physical examination of the chest revealed the signs of obstructive emphysema at the left apex, and a carcinoma of the bronchus was suspected. A chest radiograph revealed a mass at the left hilum and bronchography demonstrated that the left upper lobe bronchus was obstructed. Laryngoscopy showed the left vocal cord to have a paralysis of abduction. In October he received radiotherapy to the mediastinum, cobalt-60 being used. A dose of 2,751 rads was given over 18 days. There was some reduction in the hilar mass but no improvement of the anaemia. Immediately after the radiotherapy the reticulocyte count tended to be lower than previously and on several occasions none could be found in the peripheral blood. At the end of November smears of a marrow aspirate from the iliac crest showed normal granulocyte precursors, and megakaryocytes were present. Erythroblasts were, however, extremely scanty, numbering less than $1 \%$ of the total cell count. The patient developed a progressive thrombocytopenia, and a blood count taken just before his death in January 1963 showed his haemoglobin to be $9.9 \mathrm{~g} . / 100 \mathrm{ml}$., W.B.C. 5,800/c.mm., with normal differential count, and platelets $77,000 / \mathrm{c} . \mathrm{mm}$.

Necropsy revealed the cause of death to be diffuse gastro-intestinal haemorrhage. There was an anaplastic oat-cell carcinoma of the left upper lobe main bronchus that had metastasized to the paratracheal, peribronchial, para-aortic, and coeliac lymph nodes and to the peritoneum. There were no tumour deposits in the thoracic or lumbar vertebrae, right iliac crest, sternum, or several ribs. The marrow of all these bones was somewhat hypocellular, but red-cell precursors and megakaryocytes were identifiable. There was siderosis of the liver, spleen, and bone-marrow. The superior and anterior mediastinum contained nothing to suggest a thymoma, and microscopy revealed only a minute fragment of involuted thymic tissue.

\section{Animal Experiments}

Blood was taken from the patient in September 1962, when the diagnosis of bronchial carcinoma had been made, in an attempt to demonstrate a humoral factor capable of depressing red-cell production in experimental animals. A further specimen was taken at the end of November 1962, three weeks after the course of radiotherapy had been finished.

The animals used were adult male chinchilla rabbits. Their utilization of iron for haemoglobin synthesis was measured by giving each animal a single intraperitoneal injection of about 1.5 ml. of a buffered solution of ${ }^{59} \mathrm{Fe}$-labelled ferric citrate, each dose being approximately $4 \mu \mathrm{c}$. The amount of radioactivity injected was accurately measured in counts per second in each case. On the tenth day a specimen of venous blood was taken for the measurement of red-cell activity, haemoglobin, and P.C.V. Red-cell volume was then measured by the dilution technique using ${ }^{51} \mathrm{Cr}$-labelled red cells. The activity of all samples of blood was measured in a well-type crystal with an I.D.L. 1700 scaler. The animals were destroyed after the red-cell measurement.

Iron utilization was calculated from the formula

$$
\frac{\text { red-cell volume }(\mathrm{ml} .) \times \text { counts } / \mathrm{sec} . / \mathrm{ml} \text {. red cells }}{\text { total counts } / \mathrm{sec} \text {. injected }} \times 100
$$

The effect of the patient's serum on iron utilization was demonstrated by injecting each rabbit intraperitoneally with 4 $\mathrm{ml}$. of serum daily for five days, starting on the day before the

Experimental Results

\begin{tabular}{|c|c|c|c|c|}
\hline \multicolumn{3}{|c|}{ Injected Serum } & No. of Rabbits & Mean Iron Utilization \\
\hline $\begin{array}{l}\text { Normal } \\
\text { Patient }\end{array}$ & $\left\{\begin{array}{l}\text { Pretreatment } \\
\text { Post-treatment }\end{array}\right.$ & $\begin{array}{l}\cdots \\
\cdots\end{array}$ & $\begin{array}{l}5 \\
3 \\
2\end{array}$ & $\begin{array}{c}50 \cdot 4 \%(35-70) \\
1 \cdot 2 \%(0 \cdot 6-2 \cdot 3) \\
40.0 \%(34-46)\end{array}$ \\
\hline
\end{tabular}

radioactive iron preparation was administered. Control animals were given pooled normal serum. The two experiments with post-treatment serum were performed some months after the patient's death. The results are shown in the Table.

\section{Discussion}

The anaemia which occurs in association with a thymoma is remarkable for its severity, the reduction of reticulocytes in the peripheral blood, the lack of alteration in the leucocytes and platelets, and selective aplasia or hypoplasia of erythropoiesis in the bone-marrow. The Coombs test may at first be positive and later negative ; survival of red cells is normal or slightly reduced. Agammaglobulinaemia may develop. A terminal haemorrhagic diathesis may be seen (Andersen and Ladefoged, 1963). In the present case the anaemia was severe and the patient depended upon regular transfusions to maintain his haemoglobin level. Reticulocytes were present in the peripheral blood in small numbers, but were absent in the final illness. The leucocytes were unchanged ; thrombocytopenia occurred only after radiotherapy. The marrow showed marked erythroid hypoplasia, with normal leucopoiesis and megakaryocytes. This was reflected by poor iron utilization. The serum gamma-globulins were slightly increased. The illness was terminated by a massive haemorrhage.

There are various mechanisms by which malignant disease can cause anaemia. Chronic blood-loss or haemolysis may occur, and replacement of bone-marrow by neoplastic tissue or secondary infection may be a contributory factor. In this case none of these mechanisms appear to be relevant. The occurrence of pure red-cell aplasia with a neoplasm other than a thymoma seems to be unrecorded. The anaemia in this case was associated with the presence of a humoral factor capable of depressing iron utilization in rabbits. It is unlikely that this was the result of a non-specific toxin arising from a necrotic tumour, as it began when the tumour was so small as to be undetected. Attempts have been made by three groups of workers to demonstrate such a humoral factor in the aplasia associated with thymoma, but they have failed.

Jacobs, Hutter, Pool, and Ley (1959) gave stored patients' serum to weanling rats and measured the reticulocyte count. This method of detecting bone-marrow depression is not delicate enough and gave negative results. Ramos and Loeb (1956) gave $250 \mathrm{ml}$. of patients' plasma to a normal adult without any detectable effect on his red blood cells, neutrophils, or plasma proteins. Parry, Kilpatrick, and Hardisty (1959) failed to influence the iron utilization of rats by administering a patient's serum. Other reports indicate that plasma erythropoietic activity may be increased in red-cell aplasia (Jahsman, Monto, and Rebuck, 1962 ; Gordon and Varadi, 1962). The nature of the inhibitory factor in this case is unknown and the patient did not live long enough after the first experiments for further investigations to be made. The increase in gammaglobulins found on serum electrophoresis suggests that it may have been one of this group of proteins.

There is good evidence that bronchial carcinomata are capable of producing a variety of humoral factors with the physiological activity of other known hormones. Cases have been described of tumours which secrete substances with the activity of antidiuretic hormone, adrenocorticotrophic hormone, an oestrogen, and Parathormone (Greenberg, Divertie, and Woolner, 1964). The factors controlling erythropoiesis have not been fully identified, and if there were a naturally occurring inhibitor of erythropoiesis then by analogy with the examples quoted this might be another instance of the inappropriate secretion of a hormone by a bronchial carcinoma.

Schooley and Garcia (1962) have been able to reduce the erythropoiesis in mice by means of an antibody against erythropoietin, suggesting that an autoantibody against erythropoietin may be able to produce pure red-cell anaemia in man. 
Carcinoma of the bronchus has not been described as producing antibodies to other substances, and there is no evidence of this in the present case.

The failure of serum taken after the tumour was irradiated to inhibit iron utilization suggests that the tumour was the site of production of the abnormal substance. The possible effect of storage on this serum cannot, however, be disregarded. The failure of the anaemia to recover after treatment may be due to the dose of radiation received.

\section{Summary}

A case of carcinoma of the bronchus presenting with pure red-cell aplasia is described. A humoral factor was present in the patient's serum which inhibited iron utilization in rabbits. This factor disappeared after irradiation of the tumour, but recovery of the anaemia did not occur.
We wish to thank Professor H. Scarborough and Dr. A. H. James for permission to publish details of this case.

\section{REFERENCES}

Andersen, S. B., and Ladefoged, J. (1963). Acta haemat. (Basel), 30, 319. Gordon, R. R., and Varadi, S. (1962). Lancet, 1, 296.

Greenberg, E., Divertie, M. B., and Woolner, L. B. (1964). Amer. F. Med., 36, 106.

Jacobs, E. M., Hutter, R. V. P., Pool, J. L., and Ley, A. B. (1959). Cancer (Philad.), 12, 47.

Jahsman, D. P., Monto, R. W., and Rebuck, J. W. (1962). Amer. 7. clin. Path., 38, 152.

Parry, E. H. O., Kilpatrick, G. S., and Hardisty, R. M. (1959). Brit. med. \}., 1, 1154 .

Ramos, A. J., and Loeb, V. (1956). F. Amer. med. Ass., 160, 1317.

Schmid, J. R., Kiely, J. M., Pease, G. L., and Hargraves, M. M. (1963). Acta haemat. (Basel), 30, 255.

Schooley, J. C., and Garcia, J. F. (1962). Proc. Soc. exp. Biol. (N.Y.), 109,325 .

\title{
Simple Operation for the Overlapping Fifth Toe
}

\author{
STANLEY HULMAN,* M.B., CH.B.
}

Brit. med. F., 1964, 2, 1506-1507

An overlapping fifth toe (Fig. 1) is sometimes the cause of considerable discomfort, but often advice is sought for purely cosmetic reasons. There is no tendency to spontaneous improvement, and when uncorrected the fifth toe often becomes painful owing to pressure from the shoe.

Various methods of treatment have been described. Many authors still suggest the use of strapping applied to hold the toe in the corrected position, but this is generally regarded as of little or no value. Some writers-for example, Jones and Lovett (1929) and Perkins (1961)-suggested that amputation of the toe is advisable. This may be so in the middle-aged or elderly, but amputation ought not to be advised in the young. Amputa-
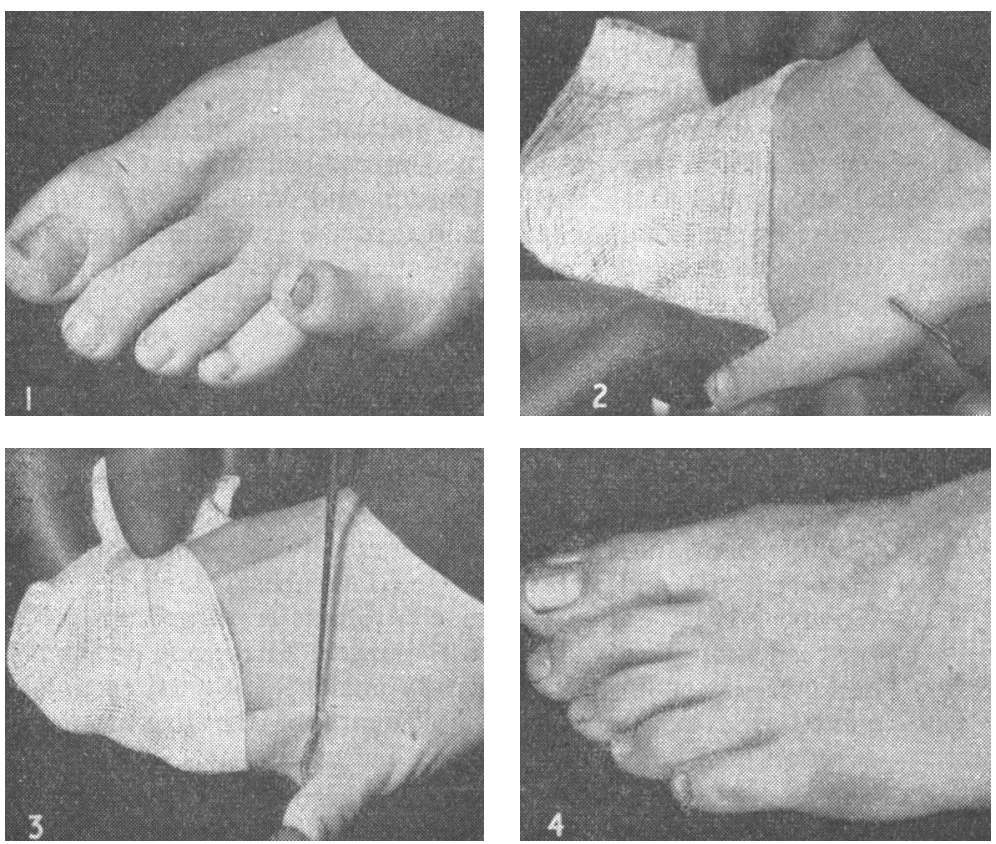

Fig. 1.-Varus fifth toe in boy aged 12. FIG. 2.- Tenotomy and capsulotomy. FIG. 3.-Approximation of skin edges. FIG. 4.-Fourteen months after operation tion predisposes to tenderness over the head of the fifth metatarsal (Stamm, 1948), and is psychologically undesirable in young people.

All the methods of operative treatment that have been described have serious limitations. One of the simplest procedures is the V-Y plastic elongation of the dorsal skin (Stamm, 1948 ; Wilson, 1953), but this sometimes leads to an ugly and keloidal scar or recurrence (Scrase, 1953).

Colonna (1950) favoured the method in which the extensor tendon is divided at its insertion and transplanted into the shaft of the fifth metatarsal, followed by division and stretching of the contracted dorsal capsule. The toe is then held for a few weeks in plaster. The illustration in his book shows a large operative scar which may tend to become keloidal and which in any event is very ugly.

McFarland (1950) used the method of " syndactylization" in which a fillet of skin is excised from the adjacent surfaces of the fourth and fifth toes. The base of the proximal phalanx of the fifth toe is removed and the adjacent edges of the raw areas are sutured together. The fifth toe is thus held permanently secured to the fourth.

The method of Lapidus (1942), in which the divided extensor tendon is threaded round the proximal part of the toe and attached to the abductor digiti minimi tendon, necessitates two dorsal incisions. It is a quite extensive operation, and in some instances the toe will later deviate into valgus.

\section{Method of Treatment}

Because of the limitations to the operations described, a relatively simple procedure has been used for some years which seems to be satisfactory. The operation consists of a subcutaneous tenotomy of the

* From the Department of Orthopaedics, St. James's Hospital, Leeds. 